\title{
Application of re/insurance models to estimate increases in flood risk due to climate change
}

\author{
Jason Thistlethwaite ${ }^{1}$, Andrea Minano ${ }^{1}$, Jordan A. Blake ${ }^{1}$, Daniel Henstra ${ }^{2}$ (D) and Daniel Scott ${ }^{3}$
}

\begin{abstract}
Background: Floods are the most common and most expensive natural hazard, and they are expected to become more frequent as the climate changes. This article presents research that used re/insurance catastrophe models to estimate the influence of climate change on flood-related losses. The geographic focus of the study was the Canadian Maritimes_-specifically Halifax, Nova Scotia_and it sought to determine how municipal risks due to rainfall-driven riverine floods could change as a result of climate change.

Results: Findings show that annual flood losses could increase by up to 300\% under a business-as-usual climate scenario by the end of the century (i.e., no mitigation or adaptation), even without accounting for changes to the built environment that could increase exposure (e.g., no population or economic growth).

Conclusions: Increasing flood risk demands an open discussion about how much risk is acceptable to the community and what controls on further growth of exposure are necessary. Moreover, projected increases in flood losses put into question long-term insurability in the Halifax area, and highlight a broader problem facing manyother areas in Canada as well.
\end{abstract}

Keywords: Flood, Catastrophe losses, Risk management, Climate change, Public policy, Insurance

\section{Background}

Catastrophe models are computer-assisted calculations that estimate financial losses resulting from natural hazard events. Created primarily for insurance purposes, catastrophe models quantify expected losses due to claims of policyholders affected by a particular hazard, such as a flood or earthquake. The information generated by catastrophe models is valuable to insurers for many reasons, including understanding their exposure to perils, informing risk-based premiums, and detecting areas that are uninsurable due to their high level of risk (Botzen and van den Bergh 2008; Lloyds 2014). Private sector catastrophe models are proprietary in nature, so access is restricted to insurers who are willing and able to invest in data and technology. As a result, they are often unavailable for public research studies and mass

\footnotetext{
* Correspondence: dhenstra@uwaterloo.ca

${ }^{2}$ Department of Political Science, Faculty of Arts, University of Waterloo,

Waterloo, ON N2L 3G1, Canada

Full list of author information is available at the end of the article
}

dissemination, and their use in the public domain is rare (Sampson et al. 2014).

However, the information generated by catastrophe models is a potentially valuable input for public policy. First, by using catastrophe models to identify areas that are particularly prone to flood damage, insurers generate damage and loss information that could be used to improve maps of at-risk communities (Surminski and Thieken 2017). Such maps could enable governments to prioritize investments in flood mitigation and encourage homeowners to purchase flood insurance. Second, catastrophe models generate loss estimates resulting from both frequent and rare floods, which could offer governments a basis to weigh the costs and benefits of flood mitigation investments (e.g., structural protections along rivers), regulate land use to reduce property exposure, and determine ways to share flood risk among governments, private stakeholders and homeowners.

Similar to global trends, flooding is Canada's largest contributor to disaster losses, estimated to account for $78 \%$ of federal disaster assistance costs (United Nations 
International Strategy for Disaster Risk Reduction (UNISDR), 2011; Parliamentary Budget Officer (PBO), 2016). Flood-related losses are influenced by several factors, including population growth and economic development in flood-prone areas, a reduction of permeable surfaces (e.g., wetlands) and the impacts of climate change (Kundzewicz et al. 2014). Climate change is a source of uncertainty for flood risk management, because physical components of the hydrological cycle are subject to change (e.g., extreme rainfall is expected to become more frequent). This changing flood regime demands accurate and up-to-date information on flood risk (Alexander et al. 2016), but existing flood maps in Canada are outdated, typically focus on a single type of flood hazard (e.g., riverine) and provide no information to estimate economic consequences (MMM Group 2014; Stevens and Hanschka 2014). However, catastrophe models that examine riverine and surface water flood risk have improved in recent years due in part to the introduction in 2015 of residential flood insurance as an optional coverage in select provinces (Calamai and Minano 2017; Meckbach 2016).

This study aims to contribute to a growing body of literature on the quantification of flood risk under the current and future climate (Bouwer et al. 2010; Feyen et al. 2009; Kundzewicz et al. 2014). For the purposes of this research, we adopted a relatively narrow definition of "flood risk" to mean potential direct economic losses associated with flooding. Re/insurance catastrophe models made available to the researchers were used to (1) quantify flood risk (i.e., direct economic losses) caused by rainfall-driven riverine flooding in residential areas, and (2) determine how the information generated can be used to inform Canadian public policy in the face of a changing climate. The models were tested in Halifax Regional Municipality, Nova Scotia-a mid-sized coastal city that has recently experienced riverine floods due to heavy rainfall (CBC 2014).

The paper begins by providing an overview of catastrophe models and Canada's current disaster management policy landscape. It then describes the study methodology, including why the study area was selected, the procedure used to map present flood risk and how future flood-related losses were estimated. The third section presents the results, with a focus on how climate change could influence flood-related losses. The paper closes with a discussion of the relevance of the results for Canadian disaster management policy and for international scholarship on flood risk in a changing climate.

\section{Climate change, catastrophe models and Canada's disaster management policy}

Climate change impacts regions across the globe in different ways, particularly in how it affects the hydrological cycle. The Intergovernmental Panel on Climate Change (IPCC) (2012), p. 13 states that "it is likely that the frequency of heavy precipitation... will increase in the $21^{\text {st }}$ century over many areas of the globe", particularly in high latitude regions like Canada. Greater precipitation will cause "increases in local flooding in some catchments or regions" (Intergovernmental Panel on Climate Change (IPCC), 2012, p. 13). The impact that climate change has had on historical flood-related losses (i.e., direct economic damages) is less clear. Socioeconomic development, rather than climate change, has been considered the primary contributor to increasing global natural hazard losses (Bouwer 2013), and increasing exposure of people and property in flood-prone areas is considered to be the primary driver of growing flood losses in recent decades (Kundzewicz et al. 2014).

Changes in the frequency and intensity of rainfall over the next century will likely create more opportunities for flood damages to occur in some regions (Rosenzweig et al. 2002; Bouwer 2013; Kundzewicz et al. 2014). Quantifying future flood risk is difficult, however, because there are many factors that influence flood losses, including uncertainties surrounding emissions pathways (Bouwer 2013). Flood risk is the product of exposure (i.e., assets likely to be affected by flooding), the frequency of occurrence (i.e., how often flooding impacts an area), and vulnerability (i.e., susceptibility to suffering damages) (de Moel et al. 2009). Climate change influences flood risk in that the probability of flooding events changes in response to greenhouse gas emissions. For example, one of the key impacts associated with different emissions scenarios is changes in the return period of extreme precipitation events (e.g., "a 1-in-20-year annual maximum daily precipitation event is likely to become a 1-in-5-year to 1 -in-15 event by the end of the $21^{\text {st }}$ century in many regions", including Eastern Canada) (Intergovernmental Panel on Climate Change (IPCC), 2012).

Perhaps due to the complexity in quantifying flood risk, there is a relatively small body of literature that explores the impact of climate change on flood losses (Bouwer 2013). Bouwer (2013), for instance, states that "there are only few studies that have translated such changes in extreme weather to economic impacts, and very little quantification is usually given of how large the impact from climate change on extreme weather losses potentially is" (p. 916). Moreover, existing studies in developed nations focus primarily on European countries and the United States, with few studies from Canadian coastal regions (Bouwer 2013; Kundzewicz et al. 2014; Lemmen et al. 2016). Efforts that quantify flood risk are beneficial particularly for determining what is at risk, estimating increases in losses over time, and analysing how policymakers and decision-makers can address these growing risks (e.g., finding a balance between risk reduction costs and benefits).

Many of the factors that influence flood risk are found in catastrophe (CAT) models (Bouwer 2013), including 
exposure, hazard and flood probability reflected as a stochastic event set (Sampson et al. 2014). The stochastic event set is composed of thousands of flood event simulations that are informed by observational data but also capture events that exceed the magnitude of historical data to capture tail-end risks (i.e., rarely occurring floods that have potentially catastrophic consequences) (Sly and Ma 2013). The event set offers a "database of extreme precipitation events over the catchment(s) that drive fluvial or pluvial risk" (Sampson et al. 2014, p. 2306). CAT models also contain location-specific information, such as the siting and characteristics of property assets, and can therefore estimate damage due to certain flood depths (depth-damage functions) to determine which assets are most vulnerable to flood-related losses (Lloyds 2014; Sampson et al. 2014). However, research coupling climate change and CAT model data is sparse, meaning there is an opportunity to make better use of this technology to inform public policy and investments aimed at reducing flood risk.

Canada and 186 other countries have adopted the Sendai Framework on Disaster Risk Reduction (Henstra and Thistlethwaite 2017b). The framework identifies four "priorities for action", which include using risk assessments to better understand disaster risk; strengthening governance to manage disaster risk; investing in disaster reduction and resilience; and enhancing disaster preparedness for effective response in order to "build back better" (United Nations International Strategy for Disaster Risk Reduction (UNISDR), 2015). Although these principles are not new-they build on a solid foundation of research that dates back more than 70 years (e.g., White 1945; Burton et al. 1978; White et al. 2001) - they have experienced a renewed emphasis as the costs of natural disasters have risen dramatically in recent years.

Despite Canada's commitment under the Sendai Framework to adopt risk assessment as the basis for disaster risk reduction, many Canadian jurisdictions lack up-to-date flood risk information (MMM Group 2014). Although the Government of Canada has a renewed effort underway to improve flood mapping (Natural Resources Canada, 2017), a lack of information has impeded efforts to prevent or reduce flood consequences on people and property. The primary objective of this research was to use CAT models to estimate the influence of climate change on flood risk in a Canadian municipality, in order to inform flood risk management decisions.

\section{Study area}

The study area consisted of the urban core of Halifax Regional Municipality (HRM), Nova Scotia, Canada-a geographically large municipality with spatially distributed populated areas, particularly along the coastline (Fig. 1). In comparison to other parts of the municipality, the urban core has the highest population density, encompassing approximately $74 \%$ of the 400,000 people who reside in HRM (Statistics Canada 2016).

HRM has a relatively mild climate compared to other parts of Atlantic Canada, with a mean annual temperature of $7.5^{\circ} \mathrm{C}$ and mean annual precipitation of $1468 \mathrm{~mm}$ (Environment and Climate Change Canada (ECCC), 2018). The city experiences few extreme hot and cold days, due to moderation by the Gulf Stream, but it faces occasional hydrological risks due to hurricanes, Nor'easter storms, and rainfall-driven riverine flooding. This research focused on rainfall-driven riverine flooding, since it had recently affected neighbourhoods in HRM and many other communities in the Canadian Maritimes (Harding 2017; Weeks 2017). Riverine flooding can occur when extreme rainfall or ice jams cause rivers to reach their capacity and overflow onto surrounding land. Since studies in Nova Scotia have focused primarily on coastal flood impacts (including sea level rise) (see Leys 2009; Lemmen et al. 2016), this study offered an opportunity to develop new knowledge about flood risks on Canada's East coast. In addition, HRM staff had recently identified a need to update their riverine flood maps and floodplain regulations-HRM restricts residential development in the 20-year floodplain but allows flood-proofed development in the 100-year floodplain (Environment and Climate Change Canada (ECCC), 2013; Berman 2016; Irish 2016).

In the event of a disaster, governments provide compensation funds to those affected. The availability of reliable climate change scenarios for this part of Canada also supported its selection as a test site for projecting the influence of climate change on flood loss estimates in the near and long-term future. Finally, the study area covered a reasonably small catchment area, which allowed the researchers to maximize the likelihood that changes in rainfall conditions caused by climate change would produce relatively uniform responses in riverine flood conditions. The next section describes the study's research design and methods.

\section{Methods \\ Mapping present flood risk}

The research was divided into two steps, each employing a distinct methodology. The first step focused on mapping the spatial distribution of present flood risk in the study area. The second step quantified financial losses resulting from various flood events under high-emission and low-emission climate change scenarios. Models produced for re/insurance purposes were used in this study to quantify present and future flood risk resulting from direct losses on residential properties.

The goal of the first part of this research was to use an existing $2 \mathrm{D}$ hydrodynamic flood model to map the location of residential properties at risk of riverine flooding (i.e., exposure to flooding), and determine 


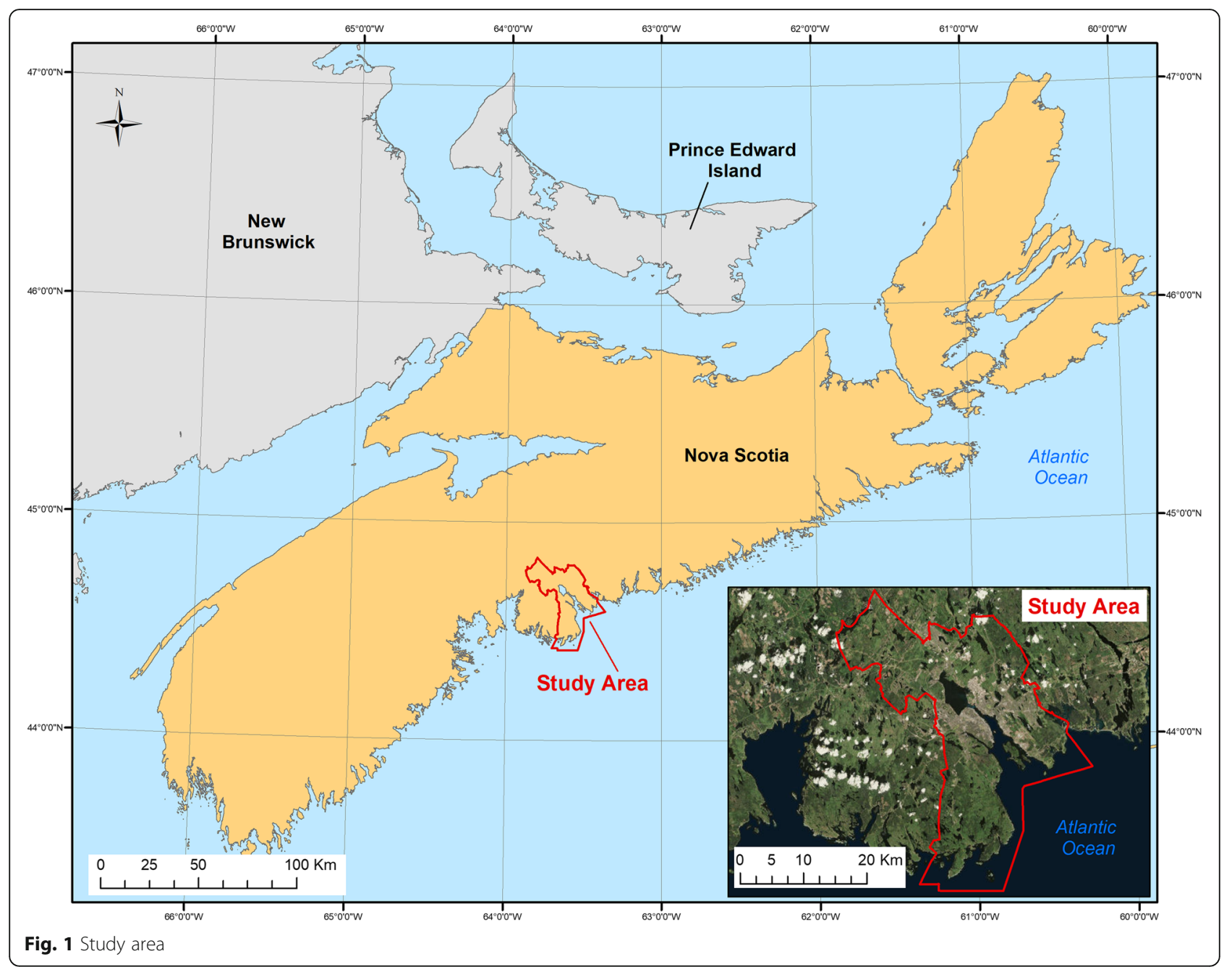

which properties had a higher susceptibility to damages than the rest (i.e., higher vulnerability). For example, not all properties susceptible to a 100-year flood would be affected equally; those located in areas where the depth and velocity of flood waters is highest would suffer the greater damages. To this end, the researchers partnered with JBA Risk Management, a firm with international expertise in natural hazard modelling, to gain access to data outputs generated by its proprietary 2D hydrodynamic flood model. This model has been used by the Canadian insurance industry to quantify the number of properties vulnerable to flooding (Parliamentary Budget Officer (PBO), 2016) and JBA's datasets assist insurers in pricing premiums for individual properties (JBA Risk Management 2018). JBA's model maps flood-prone areas in Canada by incorporating federal government data on the location of major and minor rivers, historical streamflow, and water levels, as well as other topographical and environmental inputs (Hunter et al. 2007; Lamb et al. 2009; Faulkner et al. 2016). Two model outputs were of specific interest to this research: (1) flood hazard extents, which depict the likely inundation zone for floods of different probabilities; and (2) annual damage ratios (ADR), which assign values between 0 and 1 to individual grid cells that demarcate the susceptibility to physical flood damage. Building footprints and building characteristics were retrieved from HRM to pinpoint the location of residential properties in the study area. Through a unique data-sharing agreement, this was the first study to use the model for research purposes.

Based on the data available, residential properties were considered at-risk of flooding if they were:

- classified by HRM as single-dwelling residential buildings; and

- within the 1500-year riverine flood zone (lowest probability flood event where spatial data was available); and

- within areas with an ADR value above 0, meaning the property would suffer at least some flood damages. 
Since the criteria were all spatially-explicit, a geographic information system (GIS) was used to map and quantify the number of residential buildings at risk of flooding. The spatial analysis did not, however, incorporate specific property characteristics that could reduce flood damages due to lack of available data, including property-level flood protections (e.g., backwater valves).

To create an additional subgrouping of high-risk properties, a supplemental spatial analysis was conducted. This spatial analysis associated each building footprint with an ADR value to then classify the buildings based on their vulnerability to flood damages. Buildings that intersected with multiple ADR grid cells were given the maximum damage ratio. The ADR dataset is reflective of "the expected annualized cost of flood damage at a specific location, expressed as a proportion of the sum insured" (JBA Risk Management 2017). In this study, "high risk" properties were those that were inundated by the 100-year flood (1\% probability of occurring on any given year) or more frequent events, and they had a statistically higher ADR than the rest of the properties at risk (i.e., the top 25\% of the dataset) (see Appendix 1 for further details). This qualitative classification scheme shows which properties in the study area, relative to other at-risk properties, have a higher annual probability of being flooded, and are more likely to suffer flood damages. Finally, the areas where high risk properties concentrate where identified.

\section{Modelling present and future flood-related losses}

The goal of the second part of this research was to quantify present and future losses incurred from flood damages to residential property, and how changes in losses influenced the average annual flood losses (AAL). AAL is a value that is equivalent to a "pure premium" and thus can be used as a basis for calculating risk-based flood insurance premiums available to consumers, whereby a higher AAL is likely to result in higher market premiums (Sly and Ma 2013; Lloyds 2014; Ermolieva et al. 2017). AAL is calculated "as the sum product of the mean loss and the annual likelihood of occurrence (i.e., the event rate) for each event in the [catastrophe model] event set" (Grossi and TeHennepe 2008). For this research, AAL serves as an indicative figure for detecting overall changes in the costs of flooding over time.

A second model, G-CAT ${ }^{\oplus}$ Canada Flood Model, was used for this part of the research (Guy Carpenter 2015). G-CAT ${ }^{\circledast}$ is built using JBA's hazard maps, flood defence data, and a 10,000-year stochastic event set, but it also incorporates insurance policyholder information from various Canadian insurers to calculate the financial exposure of insured assets (Contant 2015). In the HRM study area, insurance policy-level exposure information was available for about $56 \%$ of the population. The losses calculated in this study are therefore reflective of insured losses for that $56 \%$ and do not incorporate policy limits and deductibles.

G-CAT ${ }^{\varpi}$ can model the influence of many factors related to riverine risk (e.g., snowmelt), but for this study, G-CAT ${ }^{\odot}$ was used solely to model rainfall-driven riverine flooding. The decision to focus on rainfall-driven riverine losses was a result of the availability of climate change data that was used to adjust $\mathrm{G}-\mathrm{CAT}^{\oplus}$ to reflect future climate change. More specifically, climate-adjusted intensity-duration-frequency (IDF) curves at specific gauge locations across Canada have been developed in recent years (see Simonovic et al. 2016; Sandink et al. 2016). IDF curves capture the intensity of rainfall (i.e., how much rain falls over a period of time), its duration (i.e., how long this rain period lasts), and its frequency (i.e., how often this type of event occurs) (Auld 2012). These IDF curves are available publicly through an online portal that allows researchers to select temporal periods, emissions scenarios, and climate change models at various rain gauge sites across Canada.

Climate-adjusted IDF data were retrieved at a specific rain gauge site in the study area, for early-, mid-, and late-century scenarios under a $2{ }^{\circ} \mathrm{C}$ and $4{ }^{\circ} \mathrm{C}$ global temperature increase (see Appendix 2 for details). Given that G-CAT ${ }^{\otimes r} \mathrm{~s}$ flood event catalogue is defined by daily streamflow estimates, the 24-h IDF curves served as inputs for adjusting $\mathrm{G}_{-} \mathrm{CAT}^{\oplus}$ to reflect future climate change. It was assumed that precipitation changes in the study area would have a direct impact on rivers, since rivers often have similar responses to similar precipitation patterns (United States Geological Survey (USGS), 2016). This assumption allows for changing the frequency of occurrence of flood events in the entire probability curve (including low probability and high probability events) to reflect increases in the volume and intensity of precipitation under climate change. The size of the study area is best suited for this type of approach, where the relationship between a change in precipitation and flood is most evident. All loss estimates presented associated with single flood return periods (retrieved from an exceedance probability [EP] curve) and AAL, including those for future climate change, reflect the existing built infrastructure and do not account for additional risks caused by socioeconomic changes, future build up in flood-prone areas, and indirect losses.

\section{Results}

\section{Present flood risk}

Findings show that of the 54,000 single-dwelling residential buildings within the study area, $11 \%$ are at risk of suffering damages due to riverine flooding. Approximately 1300 residential properties $(2.4 \%$ of total) can be 
considered high risk based on this study's classification scheme.

By mapping the location of these at-risk properties, it was possible to identify certain zones with a high density of residential properties exposed to flood hazard across the study site. The highest concentration of flood exposure occurs along waterbodies and channels, with damage also affecting low-lying areas adjacent to these features. Researchers calculated the number of high risk properties within postal code areas to identify where high risk properties concentrate across the study area (Fig. 2).

The results from the G-CAT ${ }^{\circ}$ model estimate that a moderate probability riverine flood (100-year EP) caused by heavy rainfall under the current climate would result in CAD \$7 million in losses, while CAD \$79 million in losses from residential property damages alone emerge from a low probability flood (500-year EP). The current annual expected loss (i.e., AAL) is CAD $\$ 543,000$, whereby losses from events with an average recurrence interval of 100-years or greater are primarily influencing this value. More frequent flood events (e.g., 5-year EP) do not cause residential flood losses and thus do not contribute to the AAL. This finding is consistent with HRM's planning regulations that prevent residential development in the 20-year floodplain.

\section{Future flood risk}

Changes in flood losses due to climate change were calculated using the G-CAT ${ }^{\circledR}$ model under early-, mid- and late-century scenarios. Results show that, depending on the climate change trajectory, there are significant material differences between how flood losses change under low emissions $\left(2{ }^{\circ} \mathrm{C}\right)$ and high emissions $\left(4{ }^{\circ} \mathrm{C}\right)$ scenarios (Fig. 3). For example, due to changes in rainfall intensity expected in the study area, losses that would result from a 100-year EP flood would increase from CAD \$7 million to CAD $\$ 67$ million in a $4{ }^{\circ} \mathrm{C}$ world by the end of the century (Fig. 4). By contrast, losses for the same flood event in a $2{ }^{\circ} \mathrm{C}$ world would incur $\$ 10$ million in damages by the end of the century. The differences between the two emissions scenarios stem from differences in rainfall intensity expected to occur during a 24-h period. The 100-year rainfall (24-h duration) event under historical conditions produced $6.3 \mathrm{~mm}$ of rain per hour; but this rate changes to $6.49 \mathrm{~mm} /$ hour under a $2{ }^{\circ} \mathrm{C}$ world and $7.69 \mathrm{~mm}$ /hour under $4{ }^{\circ} \mathrm{C}$ world.

Average annual losses are projected to increase by $300 \%$ by the end of the century under a $4{ }^{\circ} \mathrm{C}$ climate change scenario (Fig. 5). Floods that have a high probability of occurring each year (e.g. 5-year EP) show little or no change in flood losses depending on the climate scenario. Meanwhile, larger floods that have a comparatively lower

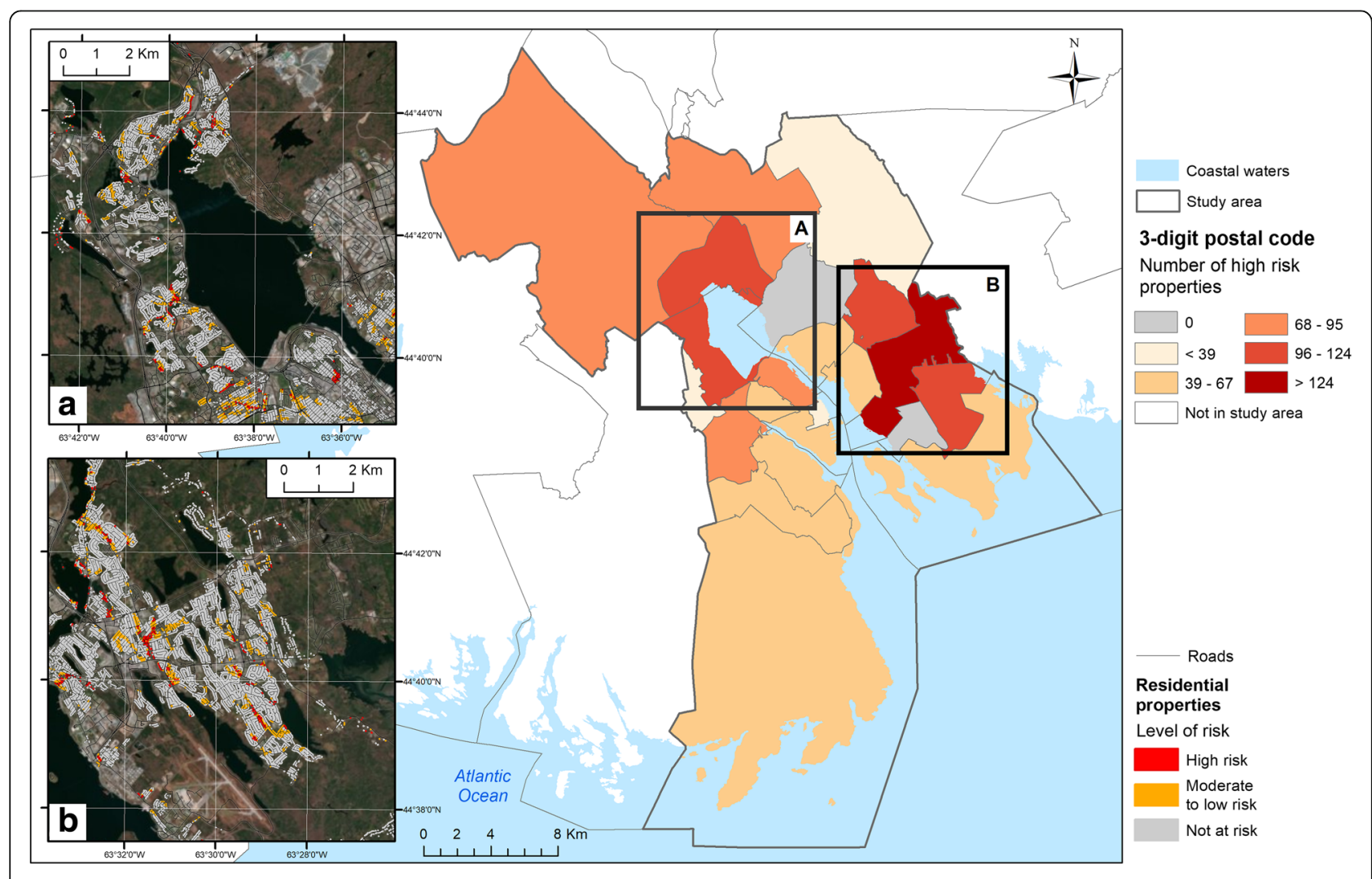

Fig. 2 Spatial distribution of flood risk in the study area. Map insets $\mathbf{a}$ and $\mathbf{b}$ show the location of residential properties at risk of flooding in parts of HRM 


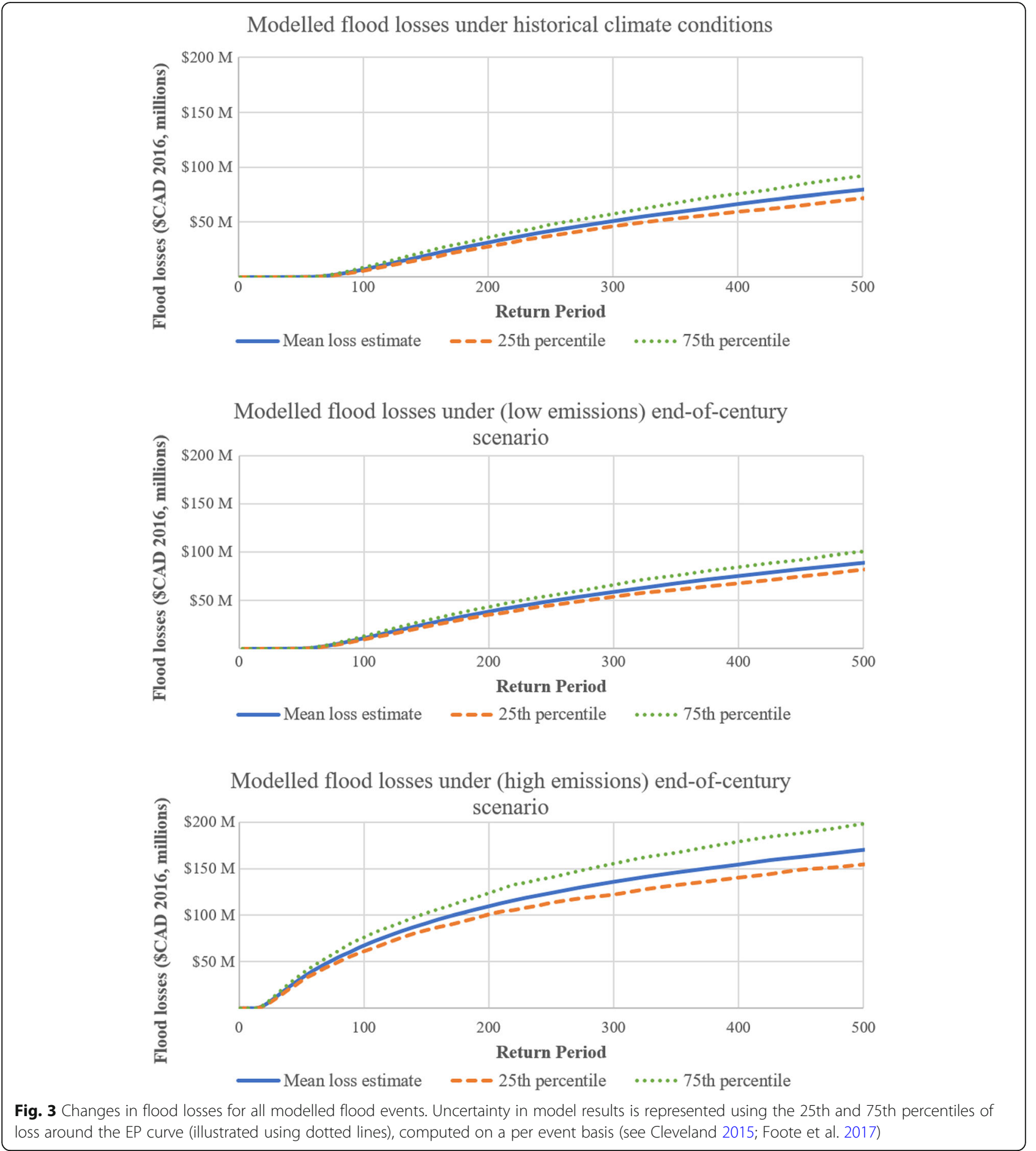

probability of occurrence each year (e.g. 100-year EP) show significant increases in flood losses under future climate scenarios. When aggregating these flood events together to calculate the AAL, the losses associated with events that have 10-year to 1000-year EP are primarily driving the increase in AAL. This suggests that present flood management is effective at handling frequently occurring floods and any climatic changes associated with these events. However, flood losses increase disproportionately in relation to comparatively lower probability-high impact events. In their analysis of the distribution of claims under the U.S. National Flood 


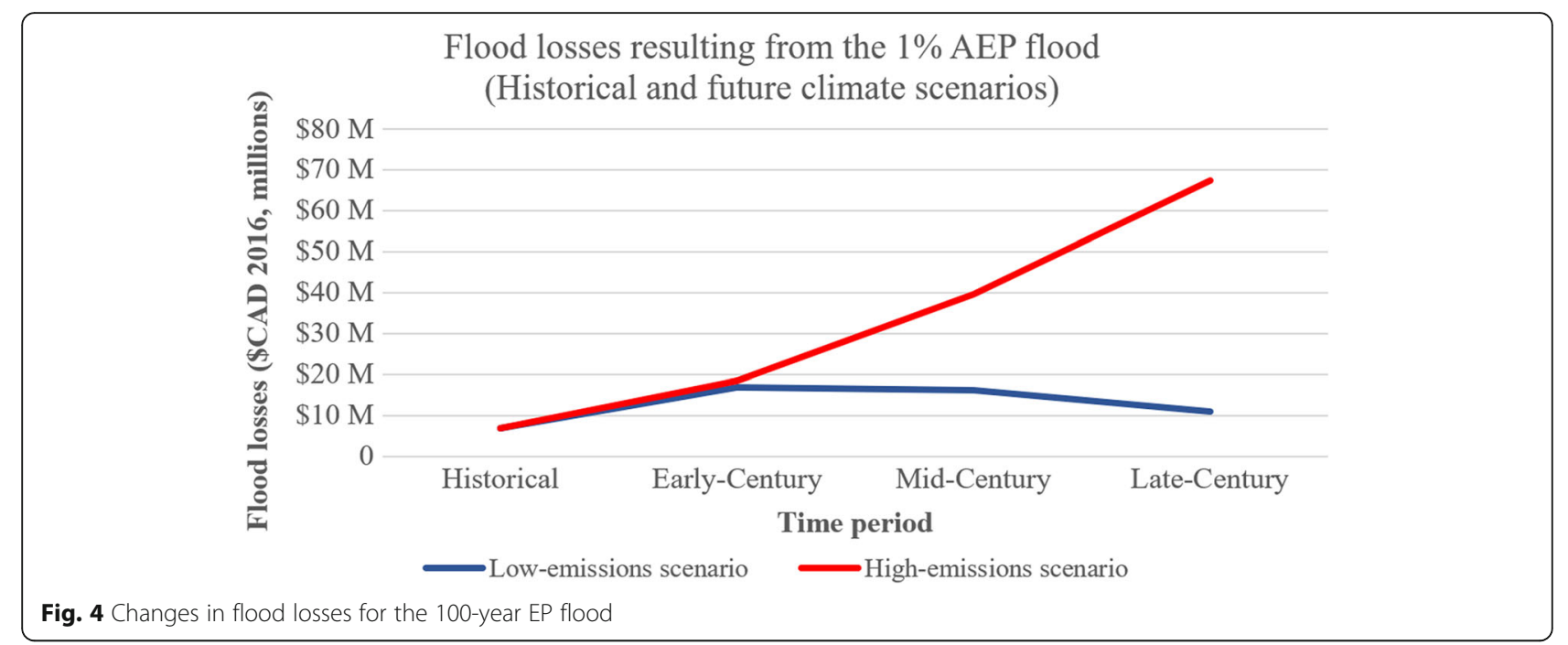

Insurance Program, for example, Cooke et al. 2014 found that "the tail of flood insurance claims seems to be getting fatter over the time period in our data. This would indicate the extremes are getting even more extreme."

\section{Discussion and conclusions}

This section discusses the relevance of research findings in relation to Canadian flood risk management policy and concludes with implications for the broader international literature.

Implications for Canadian flood risk management policy There are three main lessons for Canadian flood risk management policy. First, there is a need for frank and inclusive discussion about (1) how much flood risk is acceptable to the community; and (2) controls on further growth of exposure in these areas if the risk is deemed unacceptable. Second, the research findings support Canada's commitment to the Sendai Framework on Disaster Risk Reduction and flood risk reduction efforts. Third, projected increases in flood losses put into question long-term insurability in the Halifax area, and highlight a broader problem facing many other areas in Canada as well (Thistlethwaite 2016).

International literature explains that the "contribution from increasing exposure and value of capital at risk to future losses is likely to be equal or larger than the contribution from anthropogenic climate change" by mid-century (Bouwer 2013, p. 927). The assessment presented here estimates that average annual losses could increase by $137 \%$ by mid-century and $300 \%$ by

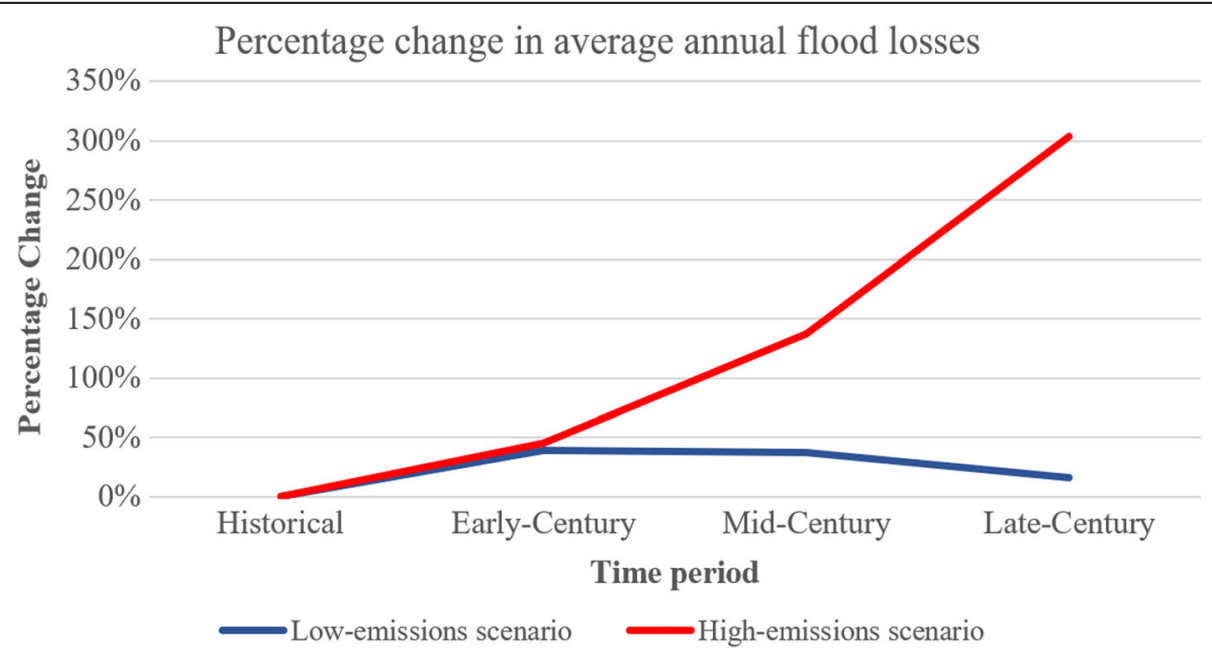

Fig. 5 Percentage change in average annual flood losses 
late-century due to climate change alone. This suggests that HRM and other municipalities facing similar risks will need to reduce property exposure by preventing the growth of exposed assets in flood-prone areas. Strict land use regulations on floodplains represent the main avenue for preventing this growth of exposure. In Nova Scotia, municipalities like HRM prevent residential development in the 20-year EP floodplain, but allow floodproofed residential development in the 100-year EP floodplain (Nova Scotia 2013). The results of this study support more strict land use regulations that mitigate risk from events that may be rare today but could become more frequent in the future (e.g., the 500-year EP event) and to enhance current land use regulations (e.g., prevent any new residential developments on the 100-year EP floodplain). These measures can limit new development in areas already vulnerable to flooding and subject to growing climate change risk during the lifespan of the property.

The results of this research support Canada's adoption of the Sendai Framework on Disaster Risk Reduction. Historically, Canada has used a primarily "structural" flood management approach, whereby engineered solutions (e.g., building dikes and levees) have been built to reduce risks, and governments were responsible for compensating victims and rebuilding to pre-disaster conditions in the aftermath of a disaster. The findings of this research show that flood risk could increase substantially over time as a result of climate change, which justifies the continued use of risk reduction measures for dealing with existing high-risk properties. This can be accomplished, in part, by ensuring that homes that are rebuilt after suffering flood damage incorporate protections, such as elevated foundations and water-resistant materials, to mitigate future flood damage (Kovacs and Sandink 2013). The provincial governments of both Nova Scotia and Alberta have offered to buy homes that were severely been damaged by floods in recent years (Cryderman 2013; Pace 2016). This strategy is best approached through an intergovernmental effort that is not currently in effect, because municipalities have reported difficulty in being able to buy out properties on their own (Deacoff 2015).

Increases in AAL reveal that insurance availability and affordability could be compromised in the future. It is estimated that there are currently $5-10 \%$ of residential properties in Canada that are not able to purchase flood insurance or be offered affordable premiums given their high-risk levels (Calamai and Minano 2017). The results of this research show that current flood risks can increase over time, meaning that residential properties will be more frequently impacted by damaging flood events. This can have two implications on private insurance markets: (1) risk-based premiums could become more expensive in the future, and (2) private insurance could become inaccessible to a growing number of homeowners due to their increasing risk levels. As governments in Canada looks to shift financial liabilities away from publicly-funded disaster assistance programs (Henstra and Thistlethwaite 2017a), governments may need to create mechanisms to address insurability gaps in high risk zones in partnership with insurers. By managing and controlling the growth of flood risks, governments can ensure that insurance remains affordable and available to most Canadian residential property owners.

\section{Relevance for international scholarship and future research}

This research contributes to the growing body of literature that focuses on quantifying flood risks across global regions. Research findings show that future flood risks could increase in HRM, and this is consistent with what is expected in European flood-prone regions as reported by Feyen et al. (2009), Bouwer et al. (2010), Te Linde et al. (2011), and Bouwer (2013). Although this study does not incorporate socioeconomic change, it does present comparable findings. For example, in the HRM study area, climate change could cause increases in AAL between $37 \%-137 \%$ by mid-century, while in the Rhine basin in the Netherlands, AAL is projected to increase from 43 to $160 \%$ by 2030 due to climate change alone (te Linde et al. 2011).

Although this study follows Bouwer's (2013) "framework for quantitative modeling of economic damages from extreme weather", it is necessary to emphasize that this study is a first assessment for quantifying flood risks in the Canadian Maritimes, and there are some limitations. One key gap is that the methodology used does not incorporate projected socioeconomic changes (e.g., population growth) and adaptation scenarios to quantify how various adaptation solutions could be most effective for reducing existing risks. Studies that compare adaptation options (e.g., structural vs. nature-based options; changes in land use) can help identify best strategies for reducing risks and promoting the realization of adaptation projects that have a positive return on investment (Lemmen et al. 2016). Second, there is a potential need to create guidelines on how to conduct climate adjusted-flood risk assessments at the local scale (e.g., data and models available, components to analyze) in order to facilitate access to this information to governments and ensuring that model outputs can be compared between jurisdictions. Finally, future studies should also capture other aspects that contribute to flood risk (e.g., public assets) as well as social vulnerability indicators since this analysis solely focused on residential property loss. 


\section{Appendix 1}

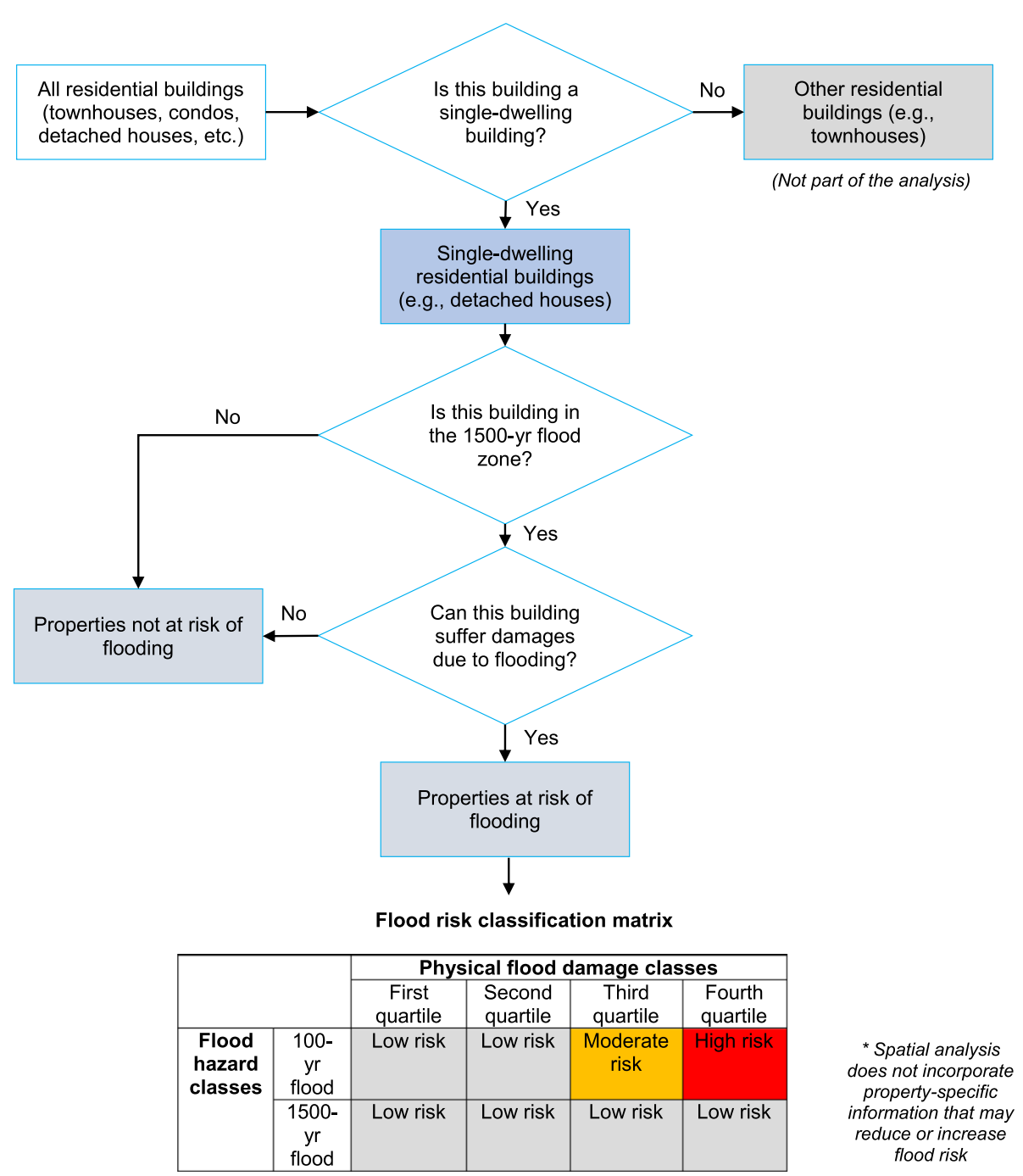

Fig. 6 Classification of at risk and high risk residential properties. Brewer and Pickle (2002) and Albano et al. (2017) served as guidance for this classification 


\section{Appendix 2}

Table 1 Sample 24-h precipitation conditions used for adjusting the G-CAT ${ }^{\circledR}$ model

\begin{tabular}{|c|c|c|c|c|}
\hline Description & Time Period & Climate scenario & Duration & Rainfall Intensity (24-h event), mm/hr \\
\hline \multirow[t]{6}{*}{ Historical conditions } & 1955-2009 & & 2 -yrs & 2.81 \\
\hline & 1955-2009 & & 5 -yrs & 3.74 \\
\hline & 1955-2009 & & $10-y r s$ & 4.36 \\
\hline & $1955-2009$ & & 25 -yrs & 5.14 \\
\hline & 1955-2009 & & $50-y r s$ & 5.72 \\
\hline & 1955-2009 & & $100-y r s$ & 6.3 \\
\hline \multirow{12}{*}{$\begin{array}{l}\text { Future Climate } \\
\text { (early-century) } \\
\text { (2015-2045) }\end{array}$} & $2015-2045$ & RCP 2.6 & 2 -yrs & 3.12 \\
\hline & 2015-2045 & RCP 2.6 & 5 -yrs & 4.06 \\
\hline & $2015-2045$ & RCP 2.6 & $10-y r s$ & 4.69 \\
\hline & 2015-2045 & RCP 2.6 & 25 -yrs & 5.46 \\
\hline & $2015-2045$ & RCP 2.6 & $50-y r s$ & 6.05 \\
\hline & $2015-2045$ & RCP 2.6 & $100-y r s$ & 6.64 \\
\hline & $2015-2045$ & RCP 8.5 & $2-y r s$ & 3.15 \\
\hline & 2015-2045 & RCP 8.5 & 5 -yrs & 4.1 \\
\hline & $2015-2045$ & RCP 8.5 & $10-y r s$ & 4.72 \\
\hline & $2015-2045$ & RCP 8.5 & 25 -yrs & 5.5 \\
\hline & $2015-2045$ & RCP 8.5 & $50-y r s$ & 6.08 \\
\hline & 2015-2045 & RCP 8.5 & $100-y r s$ & 6.68 \\
\hline \multirow{12}{*}{$\begin{array}{l}\text { Future Climate } \\
\text { (mid-century) } \\
(2035-2065)\end{array}$} & $2035-2065$ & RCP 2.6 & $2-y r s$ & 3.18 \\
\hline & 2035-2065 & RCP 2.6 & 5 -yrs & 4.11 \\
\hline & 2035-2065 & RCP 2.6 & 10-yrs & 4.69 \\
\hline & 2035-2065 & RCP 2.6 & 25 -yrs & 5.47 \\
\hline & 2035-2065 & RCP 2.6 & $50-y r s$ & 6.05 \\
\hline & 2035-2065 & RCP 2.6 & $100-y r s$ & 6.62 \\
\hline & $2035-2065$ & RCP 8.5 & 2-yrs & 3.33 \\
\hline & $2035-2065$ & RCP 8.5 & 5 -yrs & 4.34 \\
\hline & $2035-2065$ & RCP 8.5 & $10-y r s$ & 5.01 \\
\hline & $2035-2065$ & RCP 8.5 & 25 -yrs & 5.86 \\
\hline & $2035-2065$ & RCP 8.5 & $50-y r s$ & 6.49 \\
\hline & $2035-2065$ & RCP 8.5 & $100-y r s$ & 7.12 \\
\hline \multirow{12}{*}{$\begin{array}{l}\text { Future Climate } \\
\text { (late century) } \\
\text { (2065-2095) }\end{array}$} & 2065-2095 & RCP 2.6 & 2 -yrs & 3.21 \\
\hline & 2065-2095 & RCP 2.6 & 5 -yrs & 4.07 \\
\hline & $2065-2095$ & RCP 2.6 & $10-y r s$ & 4.68 \\
\hline & $2065-2095$ & RCP 2.6 & 25 -yrs & 5.41 \\
\hline & 2065-2095 & RCP 2.6 & $50-y r s$ & 5.95 \\
\hline & 2065-2095 & RCP 2.6 & $100-y r s$ & 6.49 \\
\hline & $2065-2095$ & RCP 8.5 & $2-y r s$ & 3.49 \\
\hline & 2065-2095 & RCP 8.5 & 5 -yrs & 4.62 \\
\hline & $2065-2095$ & RCP 8.5 & $10-y r s$ & 5.36 \\
\hline & 2065-2095 & RCP 8.5 & 25 -yrs & 6.31 \\
\hline & $2065-2095$ & RCP 8.5 & $50-y r s$ & 7.01 \\
\hline & 2065-2095 & RCP 8.5 & 100-yrs & 7.69 \\
\hline
\end{tabular}




\section{Acknowledgements}

We thank Guy Carpenter \& Company and JBA Risk Management for sharing their models and guiding this project. We thank Halifax Regional Municipality for providing feedback on the results of this research. GIS flood datasets provided by JBA Risk Management. Copyright JBA Risk Management Limited 2013-2017. Maps contain information licensed under the Open Data LicenseCanada (2011 datasets). Buildings data provided by Halifax Regional Municipality (2017). Map base data sources: ESRI, DigitaGlobe, Geoeye, Earthstar Geographics, CNES/Airbus DS, USDA, USGS, AeroGRID, IGN and the GIS user community 2016. All maps were created using a Universal Transverse Mercator Projection.

\section{Funding}

Social Sciences and Humanities Research Council of Canada (grant no. 4302015-00521), Canadian Water Network, Marine Environmental Observation, Prediction and Response Network of Centres of Excellence.

\section{Availability of data and materials}

Data used for this article cannot be made available, because they are proprietary and were made available to University of Waterloo through an exclusive data-sharing agreement.

\section{Authors' contributions}

JT: contributed to all sections. AM: contributed to all sections. JB: contributed to Methods and Results sections. DH: contributed to Introduction and Discussion sections. DS: contributed to Introduction and Discussion sections. All authors read and approved the final manuscript.

\section{Ethics approval and consent to participate}

N/A

\section{Consent for publication}

N/A

\section{Competing interests}

The authors declare that they have no competing interests.

\section{Publisher's Note}

Springer Nature remains neutral with regard to jurisdictional claims in published maps and institutional affiliations.

\section{Author details}

'School of Environment, Enterprise and Development, Faculty of Environment, University of Waterloo, Waterloo, ON N2L 3G1, Canada. ${ }^{2}$ Department of Political Science, Faculty of Arts, University of Waterloo, Waterloo, ON N2L 3G1, Canada. ${ }^{3}$ Department of Geography and Environmental Management, Faculty of Environment, University of Waterloo, Waterloo, ON N2L 3G1, Canada.

Received: 28 February 2018 Accepted: 25 June 2018

Published online: 11 July 2018

\section{References}

Albano, R., L. Mancusi, and A. Abbate. 2017. Improving flood risk analysis for effectively supporting the implementation of flood risk management plans: The case study of Serio Valley. Environmental Science and Policy 75: 158-172.

Alexander, M., S. Priest, and H. Mees. 2016. A framework for evaluating flood risk governance. Environmental Science and Policy 64: 38-47.

Auld, H. 2012. Climate adaptation tools: extreme rainfall intensity-durationfrequency curves, 67. Ottawa, ON: Risk Sciences International.

Berman, P. 2016. Halifax to seek federal flood prevention money for 10 sites. CBC News. 14 October. http://www.cbc.ca/news/canada/nova-scotia/halifaxregional-municipality-flood-prevention-risk-assessment-1.3803795. Accessed 16 July 2017.

Botzen, W.J., and J.C. van den Bergh. 2008. Insurance against climate change and flooding in the Netherlands: Present, future, and comparison with other countries. Risk Analysis 28: 413-426.

Bouwer, L.M. 2013. Projections of future extreme weather losses under changes in climate and exposure. Risk Analysis 33: 915-930.

Bouwer, L.M., P. Bubeck, and J.C. Aerts. 2010. Changes in future flood risk due to climate and development in a Dutch polder area. Global Environmental Change 20: 463-471.
Brewer, C.A., and L. Pickle. 2002. Evaluation of methods for classifying epidemiological data on choropleth maps in series. Annals of the Association of American Geographers 92: 662-681.

Burton, I., R.W. Kates, and G.F. White. 1978. The environment as hazard, 240 London, UK: Oxford University Press.

Calamai, L., and A. Minano. 2017. Emerging trends and future pathways: A commentary on the present state and future of residential flood insurance in Canada. Canadian Water Resources Journal 42: 307-314.

CBC. 2014. Bedford flooding, seen from a drone's point of view. CBC News. 14 December. http://www.cbc.ca/news/canada/nova-scotia/bedford-floodingseen-from-a-drone-s-point-of-view-1.2871418. Accessed 18 July 2017.

Cleveland, J. 2015. Modeling fundamentals: Uncertainty options in software. AIR Currents. 22 July. http://www.air-worldwide.com/Publications/AIR-Currents/ 2015/Modeling-Fundamentals\%2D-Uncertainty-Options-in-Software/. Accessed 1 May 2018.

Contant, J. 2015. Guy carpenter launches flood model for Canadian insurance market. Canadian Underwriter. 17 April. https:/www.canadianunderwriter.ca/ insurance/guy-carpenter-launches-flood-model-for-canadian-insurancemarket-1003576479/. Accessed 16 Aug 2017.

Cooke, R.M., C. Kousky, and E. Michel-Kerjan. 2014. Flood insurance claims: A fat tail getting fatter. Resources for the Future. 24 April. http://www.rff.org/blog/ 2014/flood-insurance-claims-fat-tail-getting-fatter. Accessed 2 May 2018.

Cryderman, K. 2013. Alberta government offers to buy homes in flood-prone areas. The Globe and Mail. 22 August. https://www.theglobeandmail.com/ news/national/alberta-government-offers-one-time-buyout-to-homeownersin-flood-prone-areas/article13914488/. Accessed 14 July 2017.

de Moel, H., J. van Alphen, and J.C.J.H. Aerts. 2009. Flood maps in Europe: Methods, availability and use. Natural Hazards and Earth System Sciences 9: 289-301.

Deacoff, C. 2015. Residential retreat: what are the government roles? Atlantic Flood Management Conference, 1-11. Truro: Nova Scotia.

Environment and Climate Change Canada (ECCC). 2013. Flood damage reduction Program https://www.ec.gc.ca/eau-water/default.asp?lang=En\&n=0365F5C2-1. Accessed 12 Oct 2017.

Environment and Climate Change Canada (ECCC). 2018. Canadian climate normals 1981-2010 station data. http://climate.weather.gc.ca/climate_ normals/index_e.html. Accessed 20 June 2018.

Ermolieva, T., T. Filatova, Y. Ermoliev, M. Obersteiner, K.M. Bruijn, and A. Jeuken. 2017. Flood catastrophe model for designing optimal flood insurance program: Estimating location-specific premiums in the Netherlands. Risk Analysis 37: 82-98.

Faulkner, D., S. Warren, and D. Burn. 2016. Design floods for all of Canada. Canadian Water Resources Journal 1784: 1-14.

Feyen, L., J.I. Barredo, and R. Dankers. 2009. Implications of global warming and urban land use change on flooding in Europe. In Water and urban development paradigms: Towards an integration of engineering, design and management approaches, ed. J. Feyen, K. Shannon, and M. Neville, 217-225. Boca Raton, FL: CRC Press.

Foote, M., K. Mitchell-Wallace, M. Jones, and J. Hillier. 2017. models. In Natural catastrophe risk management and modelling: A Practitioner's guide, ed. K. Mitchell-Wallace, M. Jones, J. Hillier, and M. Foote, 297-381. Oxford, UK: Wiley.

Grossi, P., and C. TeHennepe. 2008. Catastrophe modelling fundamentals. In A Guide to Catastrophe Modelling, ed. R. Lythe, 6-9. Colchester, UK: Informa UK Ltd.

Guy Carpenter. 2015. Guy Carpenter launches new G-CAT ${ }^{\circledR}$ Canada flood model. http://www.gccapitalideas.com/2015/04/16/guy-carpenter-launches-new-gcat\%C2\%AE-canada-flood-model/. Accessed 12 Oct 2017.

Harding, G. 2017. New Brunswick flood more inconvenience than catastrophe. CBC News. 7 May. http://www.cbc.ca/news/canada/new-brunswick/heavyrain-over-river-above-flood-stage-1.4103542. Accessed 12 Nov 2017.

Henstra, D., and J. Thistlethwaite. 2017a. Climate change, floods, and municipal risk sharing in Canada, 48. Toronto, ON: Institute on Municipal Finance \& Governance.

Henstra, D., and J. Thistlethwaite. 2017b. Overcoming barriers to meeting the Sendai Framework for Disaster Risk Reduction. Centre for International Governance Innovation, Policy brief no. 105. https://www.cigionline.org/sites/default/files/ documents/PB\%20no.105web_0.pdf. Accessed 18 Nov 2017.

Hunter, N.M., P.D. Bates, M.S. Horritt, and M.D. Wilson. 2007. Simple spatiallydistributed models for predicting flood inundation: A review. Geomorphology 90: 208-225.

Intergovernmental Panel on Climate Change (IPCC). 2012. Managing the risks of extreme events and disasters to advance climate change adaptation. Cambridge, UK: Cambridge University Press 582 pp. 
Irish, D. 2016. Halifax to study Sackville River watershed flooding risk. CBC News. 29 January. http://www.cbc.ca/news/canada/nova-scotia/sackville-river-floodrisks-study-1.3425513. Accessed 12 Oct 2017.

JBA Risk Management. 2017. Annual damage ratio datasets. http://www.jbarisk. com/our-datasets/annual-damage-ratio-datasets. Accessed 12 Oct 2017.

JBA Risk Management. 2018. Analytics to manage your flood risk. http://www.jbarisk. com/flood-services/maps-and-analytics/analytics/. Accessed 19 June 2018.

Kovacs, S., and D. Sandink. 2013. Best practices for reducing the risk of future damage to homes from riverine and urban flooding. Toronto, ON: Institute for Catastrophic Loss Reduction $30 \mathrm{pp}$

Kundzewicz, Z.W., S. Kanae, S.I. Seneviratne, J. Handmer, N. Nicholls, P. Peduzzi, and R. Muir-Wood. 2014. Flood risk and climate change: Global and regional perspectives. Hydrological Sciences Journal 59: 1-28.

Lamb, R., M. Crossley, and S. Waller. 2009. A fast two-dimensional floodplain inundation model. Water Management 62: 363-370.

Lemmen, D.S., F.J. Warren, T.S. James, and C.S.L. Mercer-Clarke. 2016. Canada's marine coasts in a changing climate, 274. Ottawa, ON: Government of Canada.

Leys, V. 2009. Sea-level rise and storm events. In The state of Nova Scotia's coast, ed. J. Walmsley, 160-176. Halifax, NS: Government of Nova Scotia.

Lloyds. 2014. Catastrophe modelling and climate change, 41. London: Lloyds of London.

Meckbach, G. 2016. Economical insurance to launch overland flood coverage in 2016. Canadian Underwriter. 1 May. https://www.canadianunderwriter.ca/ insurance/economical-insurance-launch-overland-flood-coverage-20161004090282/. Accessed 27 Sept 2017.

MMM Group. 2014. National floodplain mapping assessment: final report, 68. Ottawa: Public Safety Canada.

Natural Resources Canada. 2017. Federal floodplain mapping Framework, 20 Ottawa: Natural Resources Canada.

Pace, N. 2016. Nova Scotia government to buy 18 homes damaged in Cape Breton flood. Global News. 8 December. https://globalnews.ca/news/ 3114521/n-s-government-to-buy-18-homes-damaged-in-cape-breton-flood/. Accessed 12 Oct 2017.

Parliamentary Budget Officer (PBO). 2016. Estimate of the average annual cost for disaster financial assistance arrangements due to weather events, 49. Ottawa, ON: Office of the Parliamentary Budget Officer.

Rosenzweig, C., F.N. Tubiello, R. Goldberg, E. Mills, and J. Bloomfield. 2002. Increased crop damage in the US from excess precipitation under climate change. Global Environmental Change 12: 197-202.

Sampson, C.C., T.J. Fewtrell, F. O'Loughlin, F. Pappenberger, P.B. Bates, J.E. Freer, and H.L. Cloke. 2014. The impact of uncertain precipitation data on insurance loss estimates using a flood catastrophe model. Hydrology and Earth System Sciences 18: 2305-2014.

Sandink, D., S.P. Simonovic, A. Schardong, and R. Srivastav. 2016. A decision support system for updating and incorporating climate change impacts into rainfall intensity-duration-frequency curves: Review of the stakeholder involvement process. Environmental Modelling \& Software 84: 193-209.

Scotia, Nova. 2013. Statements of Provincial Interest made under Section 193 and subsections 194(2) and (5) of the Municipal Government Act. https:// novascotia.ca/just/regulations/regs/mgstmt.htm. Accessed 20 June 2018.

Simonovic, S.P., A. Schardong, D. Sandink, and R. Srivastav. 2016. A web-based tool for the development of intensity duration frequency curves under changing climate. Environmental Modelling \& Software 81: 136-153.

Sly, G., and N. Ma. 2013. Modelling fundamentals: What is AAL? AIR Currents. 25 March 2013. http://www.air-worldwide.com/Publications/AIR-Currents/2013/ Modeling-Fundamentals-What-Is-AAL-/. Accessed 4 Aug 2017.

Statistics Canada. 2016. Census Profile, 2016. http://www12.statcan.gc.ca/censusrecensement/2016/dp-pd/prof/index.cfm?Lang=E. Accessed 12 Oct 2017.

Stevens, M.R., and S. Hanschka. 2014. Municipal flood hazard mapping: The case of British Columbia, Canada. Natural Hazards 73: 907-932.

Surminski, S., and A.H. Thieken. 2017. Promoting flood risk reduction: The role of insurance in Germany and England. Earth's Future 5: 979-1001.

Te Linde, A.H., P. Bubeck, J.E.C. Dekkers, H.D. Moel, and J.C.J.H. Aerts. 2011. Future flood risk estimates along the river Rhine. Natural Hazards and Earth System Sciences 11: 459-473.

Thistlethwaite, J. 2016. The emergence of flood insurance in Canada: Navigating institutional uncertainty. Risk Analysis 37: 744-755.

United Nations International Strategy for Disaster Risk Reduction (UNISDR). 2011. Global assessment report on disaster risk reduction: Revealing risk, redefining development, 178. New York: United Nations.
United Nations International Strategy for Disaster Risk Reduction (UNISDR). 2015. Sendai framework for disaster risk reduction 2015-2030, 37. New York: United Nations.

United States Geological Survey (USGS). 2016. Streamflow: The Water Cycle. https:// water.usgs.gov/edu/watercyclestreamflow.html. Accessed 3 Oct 2017.

Weeks, J. 2017. Flood-damaged road section off Cabot Trail won't reopen for weeks, CBC News. 9 May. http://www.cbc.ca/news/canada/nova-scotia/road-closuretransportation-cape-breton-flood-washout-1.4107080. Accessed 3 Oct 2017.

White, G.F. 1945. Human adjustment to floods: A geographical approach to the flood problem in the United States. Chicago: University of Chicago 225 pp.

White, G.F., R.W. Kates, and I. Burton. 2001. Knowing better and losing even more: The use of knowledge in hazards management. Environmental Hazards 3: 81-92.

\section{Submit your manuscript to a SpringerOpen ${ }^{\circ}$ journal and benefit from:}

- Convenient online submission

- Rigorous peer review

- Open access: articles freely available online

- High visibility within the field

- Retaining the copyright to your article

Submit your next manuscript at $\gg$ springeropen.com 